Sharma, P. R., 1977. "Caste, Social Mobility and Sanskrititization: A study of Nepal's Old Legal Code". In Kailash Vol. 4 No. 5 (pp. 277. 300).

Sherratt, A., 1990, "The genesis of Megaliths: Monumentality, Ethnicity and Social Complexity in Neolithic north-west Europe". In World Archaeology Vol. 22 No. 2 Monuments and Monumental London: Routledge

Slusser, M. S. 1982., Nepal Mandala: A Cultural Study of the Kathmandu Valley. Volume 1:Text. Princeton, New Jersey: Princeton University Press.

Tilly, C. 1994., A Phenomenology of Landscape: Places, Paths and Monuments . Oxford: Berg

Tuan, Yi-Fu., 1974. Topophilia: A study of Environmental Perception, Attitudes and Values. Englewood Cliffs. NJ: Prentice-Hall.

Turner, V., 1967. The Forest of Symbols: Aspects of Ndembu Ritual. Ithaca: Cornell University Press.

Ucko, P. J. "Foreword". In Sacred Sites, Sacred Places. David L. Carmichael, Jane Hurbert, Brian Reeves and Audhild Schanche (eds.). London: Routledge.

\section{DEVELOPMENT OF WATER SUPPLY AND SANITATION FACILITY IN THE RURAL AREAS OF NEPAL: AN OVERVIEW}

Jiba Nath Prasain*

\subsection{Introduction}

Safe drinking water is the basic necessity for people. Traditionally as well as culturally, Nepali people believe that flowing water is considered "pure" and "safe" for drinking and domestic purposes. Water is a multifaceted symbol in Hinduism. It is regarded as one of the panchatatawa, i.e., five primeval elements of the universe along with the earth, fire, air, and ether...water was sacred precisely because it had the potential to wash away the sin. Just as water dissolves away dirt and mud, so too does it dissolve sin. Water was regarded as papamochana, or that which frees one from sin and impurity. A person was regarded as being clean after a ritual bath, or snana. While the symbols of water as a primal matter, an instrument of purification and expiation, a unifying force and a vivifying element can all be found in Hinduism, in most of the dharmashastras, or Hindu religious texts, the symbolism of water as an instrument of purification and expiation, is pre-eminent (Sharma, 2001:37-38). As water is purifier element, women take bath for purification after delivering baby, during the death observance ritual, people take bath to purify, cleaning sins, to gain religious merits, or to perform any sorts of religious activity, taking bath is most essential part of Hindu rituals. Rig-

* J. N. Prasain is an anthropologist by discipline and worked as a free-lance development consultant in bilateral agencies Nepal and UN agencies outside Nepal. 
Veda, Atharva Veda, Manusmriti, and Arthashastra are the one those stated the use and importance of water for ritual cleanliness. Sudhindra Sharma, in his book "Procuring Water" (2001) clearly pointed out the importance of water in Hindu socio-cultural life as: among Hindus many of the daily, yearly and life-cycle rites such as daily bathing, bathing in the rivers during certain auspicious days of the year and cremation as well as cremation-related annual rites are conducted along the river banks. Water was and is associated intricately with many religious purification rituals. However, the 'modern concept of drinking and domestic water' has overlooked the ritual purification-aspects of water. And it is seen from the perspectives of easy accessibility, nearness, adequate quantity \& quality, reduction of water-borne and water-related diseases, and lessen the drudgery of women and children (The National Water Sector Policy, 1998), rather spiritual purification.

Traditionally, most development activities in Nepal were based on indigenous initiatives. Parma, pareli, guhar, etc --the traditional forms of labor exchange or communal co-operation in rural Nepal (Blaikie, et al., 1982, and Pyakuryal, 1993)-- are the common community efforts in agricultural activities as well social development efforts such as building houses, pati-pauwa, dharmasala, and chautari (different sorts of resting-places) and many other community infrastructural facilities such as irrigation canals, foot trails and drinking water schemes.

The 'so-called' modern model of community development or the organized form of rural development has started along with the Tribhuvan Gram Bikas (Pradhananga, 1991), which was the first government-initiated rural development program in 1950 s. Prior to that time, the rural people had managed their community development activities without foreign assistance. Development should be for the satisfaction of essential human needs (Alexander,1994).

It can be stated that the development is an on-going process. Development implies positive changes. It may be defined as those changes, which are seen as desirables among the particular group of people who are changing (Axinn, 1978)
There is the multiplicity of the sources of rural water supply which comprise river, dhunge dhara (stone spout), kuawa (surface well), pokhari/kunda (pond dug-well), shallow tubewell, spring to gravity feed/overhead water supply system. When people know about advance technology through different ways, they want to have it provided that is affordable, and materials and technologies are easily available or that they have the ability to pay and willingness to pay for it. In the ancient time, most of the human settlements were established and civilizations developed along the banks of rivers. The paper is intent on fulfilling two objectives. They are: (i) to analyze briefly the policy trend and development practices of rural water supply and sanitation activity, and (ii) to assess the roles of the beneficiaries to make the rural water supply and sanitation activity sustainable. The author has tried to fulfill these two objectives of the paper by utilizing the secondary sources of the relevant information.

\subsection{Genesis of Rural Water Supply and Sanitation Development Activities in Rural Nepal}

Drinking water is the most important basic need of the human beings. It remains on the top priority in the agenda of rural development. Given the fact that the 'modern organizational/governmental' efforts to develop drinking water supply sector has not had long history as a systematic approach. The Ministry of Water Resources was originally held responsible for all the drinking water supply under its Department of Irrigation and Water Supply, which was established in 1966, and the department was performing its roles till 1971. And in 1972, under the umbrella of the Ministry of Water Resources, the responsibilities for irrigation and drinking water were separated and the Department of Water Supply and Sewerage (DWSS) was created. At that time, the Ministry of Panchayat and Local Development (MPLD) had been given the responsibility for small-scale village level water supply scheme construction as part of its local development program. Criteria for such schemes developed by MPLD were as follows: (i) a system should serve maximum of 1500 people, (ii) the pipeline should not be longer 
than 5 kilometers and (iii) the cost should not be more than NRs. $50,000.00$. Those schemes that did not meet the above stated criteria were managed by DWSS through consultants and or contractors' involvement for construction of the schemes under the Ministry of Water Resources (Boot and Heijnen, 1988). This structure lasted for 15 years. Till 1970, the national water supply coverage was only $3.7 \%$ of the total population of Nepal (Sharma, 2001) and it was extremely low in the rural area of Nepal. It was out of planners' priority area of improving the water supply and sanitation condition in rural area.

In the decade of 1970 s, in the international arena, two women, one British economist-Barbara Ward, and the other American anthropologist-Margaret Mead individually initiated the activity for drinking water supply at the United Nations (UN) Conference on Human Settlement (HABITAT) in Vancouver, 1976. They emphasized for favorable policy formulations and approvals on water supply and sanitation. The following year, at the World Water Conference- Argentina, was carried forward with the specific recommendations so that the UN created a tenyear program to focus on water and sanitation. The General Assembly of UN subsequently passed the resolution creating the International Drinking Water Supply and Sanitation Decade: 1980-1990 (Bourne, 1984). To express the commitment on the International Drinking Water and Sanitation Decade, HMGNepal's stated its priority concern to have accessible piped drinking water supply by the end of 6th five -year plans. It is mentioned in the Seventh [Five -Year] Plan that only $17.9 \%$ and $79.9 \%$ of rural and urban people, respectively, would have access to drinking water. But it did not mention the actual coverage in the achievement of the 6th Five Year Plan. The column of achievement is blank (Seventh Plan, 2042-2047 B.S). Likewise, it was mentioned in the Eight Plan the target was set 72 percent of population coverage of drinking water supply, but actually by the end of the Eighth Plan only 61 percent were covered (Ninth Plan, 1998). The separation of the Department of Irrigation and Department of Water Supply and Sewerage
(DWSS) has been recognized in 1984/1985. These two departments were set up under separate ministries i.e., Ministry of Water Resources and Ministry of Housing and Physical Planning (MHPP), respectively. A few years later (1988), the MHPP had to shoulder the responsibility of formulation and steering the implementation of overall policies and strategies for water and sanitation sector and for inter-related sectoral coordination. It is stated that $80 \%$ people have access to improved water supply and sanitation coverage is only $27 \%$ (UNDP, 2001).

\subsection{Organizations/Institutions Involved in Drinking Water and Sanitation Development Activity}

During and after the Water and Sanitation Decade, in addition to the Nepali Government efforts, United Nations Children's Funds (UNICEF), United Mission to Nepal (UMN), Lutheran World Service (LWS), Red Cross Society, HELVATES, Finish International Development Agency (FINNID)- Rural water Supply and Sanitation Project (RWSSP), Danish International Development Agency (DANIDA), European Commission (EC), Water Aid, Save the Children Fund United Kingdom (SCF-UK), Save the Children Fund United States of America (SCF-USA), Redd Barna, World Bank, Asian Development Bank, (RWSS- FUND) FUND Board and numbers of other Community Based Organizations (CBOs) have been involved in providing water and sanitation services and facilities in the rural area of Nepal. These are not exhaustive name list, but these are only some of the principal institutions/organizations working in this sector.

\subsection{Directions of Rural Water Supply and Sanitation Development Initiatives}

Traditionally, Nepal has the strongest and richest heritage of people's participation in community development 
activities. History shows that development usually takes places not through external interventions but through ordinary people working collectively to meet their felt needs (whatever pattern of participation). In Hindu societies, the construction of traditional water points is regarded as a sacred activity (Pandey, 1992). They spent money for the construction of temples, water supply systems, rest houses, bridges, and paved roads to gain religious merit (Bista, 1994). It was sporadic, individually initiated, and motivated by benevolent intentions. Or may be to keep the power and influence over the poor by the rich which could give the continuation of traditional patron-clients relationship in a covert way. When the "modern" or "organized planned development" activity started, the "top down" or "centralized approach" took over the traditional form of people's participation. The notion of people's participation in drinking water supply was initiated by MPLD, which had taken responsibility of the construction of small-scale drinking water supply projects like others such as roads, suspension bridges, and foot-trials. However, it was mainly on the cost reduction approach or "cheap labor", "cost sharing", "contractual obligation"(Srinivasan, 1990). And concept and practice on "community decision-making" was not institutionalized during the course of intervention. Mainly technicians decided the water supply scheme according to the pre-set guidelines and they just asked the community to contribute necessary labor and locally available materials and assigned the role of operation and maintenance of the constructed schemes.

It was the general practice during 1970s that technocrats undermined and even overlooked the importance of partnership approach in development... that the men and women of the village of Nepal are a critical components of the development of the country (Stiller \& Yadav, 1979), which was neglected. Any development activity could fail when it fails to involve and encompass the mental attachment and physical involvement of people to decide what they want for them. If neglected, this certainly creates the "dependency syndrome" rather than the "sustainability". The two decades of these types of conceptual backgrounds, which consequently laid the foundation stones to recognize the importance of people's participation in decisionmaking. But there is a genuine question: why the crucial idea of "ownership feeling' has not been generated in the mind of the people, who actually benefit from such activity? It could be due to one or a number of reasons such as: the continuous flow of foreign aids without doing proper homework, lack of awareness on the part of people and utilization of development work for political benefits (Giri, 1992). Consequently, "psychic of people" became more dependent on outside assistance and the crisis of confidence was/is common (Prasain, 1996) among the community members and between community and outsiders. But the irony is that those who enjoyed the benefits continued to be increasingly unhappy and asked for more without contributing to the process of development (Bista, 1994). In addition, other reasons behind could be myopic vision and passing responsibilities to others' shoulders by our top politicians/planners, which accentuated in the process of erosion of community self-motivation, and self-help approach. These observations are also corroborated by the researcher's own discussions held with the beneficiaries of LWS project in Baglung and RWSSP project Lumbini Zone. During the later part of 1980s, there were some NGOs, which initiated the process of giving some percentage of maintenance funds (benevolently) to deposit in the users' bank account after the completion of a water supply scheme. It is interesting to note that the Nepal Red Cross \& Lutheran World Service (LWS) funded Water Resources Development Project (WRDP) in Baglung (during 1984-1986 project cycle) had deposited half $(2.5 \%)$ of the maintenance fund in the users' bank account and half was deposited by users themselves to operate and maintain the completed drinking water supply schemes. And for the sake of improving environmental sanitation and personal hygiene, a 
concrete slab for pit latrine had been provided free of cost to each family, where drinking water supply schemes were implemented. After a year, it was clear that both the activities initiated with good intention did not work. Then, the project shared the information with community members about the guidelines (formulated in consultation with them) that after the completion of socio-economic and technical feasibility studies of a scheme; the users were asked to collect and deposit the required amount of fund for maintenance. Then, only the project would finalize detailed cost estimate of quantity required for a scheme. Materials for water supply would be disbursed when users' produced the bank voucher for the maintenance fund deposited in the users' bank account, and if household had collected the necessary materials for constructing latrine slab, cement and technicians could be provided.

\subsection{User's Participation: A New Paradigm and a Paradox}

The word 'community participation or people's participation' has different meanings to different people. It has become 'buzz word' among the development professionals in the recent decades. "Community participation" or "people's participation" does suffer from problems of definition; it means different things to different people, depending upon their perspectives. No threshold point separates "participation" from "nonparticipation". "Community participation" is, therefore, usually defined in terms of a typology that represents increasingly intensive degrees of involvement in: (i) planning programs and projects, (ii) implementing projects, (iii) sharing in benefits of projects, and (iv) evaluating projects. The UN Decade approach to drinking water supply and sanitation stressed that for national projects to be acceptable for external finding, some degree of community participation must be demonstrated in relation to all four criteria (White, 1984: 221-222). But Lohani, (1980) is of the opinion that the closest synonym of people's participation is popular participation. Various resolution of UN bodies have identified mass sharing of benefits of development, mass contribution to development, and mass involvement in decision-making process of development as the three basic ingredients of popular participation (Lohani,1980). Selener has quoted (from Conchelos, 1985) two types of participations in his book 'Participatory Action Research and Social Change' (1998), namely, participation of a technical nature can be manipulated by the power holders to fulfill their own needs and thus may not promote empowerment of social change... and participation of a political nature means acquiring power and taking greater control of a situation by increasing options for action, autonomy and reflection, especially through the development and strengthening of institution (Selener, 1998: 204). And another meaning of participation is that the participation by the people in the institutions and systems, which govern their lives, is a basic human right and also essential for realignment of political power in favour of disadvantaged groups and for social and economic development. Rural development strategies can realise their full potential only through the motivation, active involvement and organsation at the grassroots level of rural people, with special emphasis on the least advantaged, in conceptualising and designing policies and programmes and in creating administrative, social and economic institutions, including cooperative and other voluntary forms of organsation for implementing and evaluating them (FAO quoted by Burkey, 1993). Analyzing the above definitions, the concerned people's involvement in all project cycles is the meaningful one to decide what they really want and can do to determine their future life.

The philosophy of "top down", "donor driven", "technocratic, bureaucratic", and "provisioning" approaches in rural development could not work well either from the empowerment or from sustainability point of view. Many scholars and development practitioners have collected ample examples in this regard. Among these, Trace and Whiteside 
made observations and said that technicians took decisions. As a result, water supply programmes are almost invariably headed by engineers rather than community development specialists ... (Trace, S., et al., 1992). Ultimately, the community members do not hold the "sense of ownership" and consequently after some time, like other development initiatives, water supply schemes are found dysfunctional.

In the decade of $1980 \mathrm{~s}$, in rural water supply and sanitation sector, a remarkable step took place, at least in conceptual guidelines, which set criteria on how to make the system more people-friendly. According to the guidelines and set criteria, a request for a drinking water scheme should be lodged with Local Development Department (LDD) by the village Panchayat through the district Panchayat. But, despite this arrangement, in practice, a number of projects were directly requested through political channels or influential leaders. These projects were usually less successful, as implementation was frequently delayed because of disputes about the source of water and tap locations or other internal conflicts, or by a lack of community motivation for voluntary labor. In January 1980, 10 out of 44 projects water supply schemes under construction suffered from these problems. ... However, experience has demonstrated increasingly that the success of a water supply scheme very much depends on a real partnership between program staff and community (Boot \& Heijnen, 1988). In FINNIDA/HMG-N- funded RWSS Project (1990-1996 phase) in a village, named Saljhandi of Rupendehi district-Lumbini Zone, it took more than a month to decide one out of thirty-two water points (water taps), but implementation was very smooth after it. This was the result of good facilitation of the interventionists together with the provisioning of appropriate knowledge and skill.

It is still more or less the same pattern or approach as 1980 s regarding the sustainability and ownership of any rural development activity. In this regard, D. E Setty holds the opinion that weaker sections of the users' are seldom involved in policy and decision-making activities (except in labor contribution). Conversely, the rural elites are involved in these matters who neither contribute labor nor play an effective supervisory role. And the consequence is the failure of the project activities (see figure : 1). In this regard, R. Chambers also pointed out that decisions are taken either by the urban-based bureaucrats, technocrats, or "so called" development workers and or rural elites - the non-concerned outsiders. The interests of these may slant towards other direction than the real beneficiary. Such directly non-concerned people could be entrenched by many rural developments biases- spatial, project, person, season, diplomatic and professional biases- (Chamber, 1983). In most of the cases of rural development initiatives like in Nepal, people's participation in the project cycles is a 'token participation' in the context of empowering the poor people (especially women who are the prime users of water). If it is not duly recognized, how can the sustainability be ensured? In such a situation, sustainability of development efforts, including water and sanitation activity, would be rhetoric, myth and or a mockery.

Figure: 1 Pattern of Participation in Rural Development

Socio-economic Category

Pattern of Decision-Making

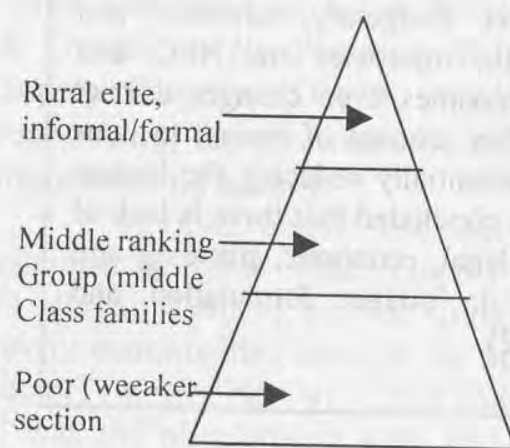

Policy matters, decision making, planning Leaders for implementation-monetary and materials contribution and not labour contribution and Play a supervisory role.

Occasionally in decisionmaking and planning, contribution of money and materials and negligible Labour contribution

labors seldom involve in policy matter and decisionmaking. Contribution if any chiefly, labours and minors chores

Source: Setty, D. E., 1985, The Indian Journat of Social Work, Vol. XLVI, No.1 (April1985) 
The overall scenario of rural development has been continuously shadowed by the "top down" or "centralized development model". In Nepal, even though these days, government has put the "decentralization and good governance" on the top priority concern, the genuine people's participation (empowerment) and real decentralization are far-fetched dreams. As the Chairman of Kabre District Development Council (DDC) and President of DDC of Nepal, Mr. Krishna Prasad Sapkota, vividly pointed out the present pattern, practice and psychic of the top policy making body:

\section{Box: 1}

What happens to decentralize planning in practice?

That the National Planning Commission (NPC) and line ministries always violets the minimum norms of decentralized planning in several ways. The NPC sets district budget ceiling that often fail far below the minimum needs of the district, and that even writing the total budget ceiling, sectoral ceilings are prescribed so haphazardly that the DDC can not set its district priorities. He contends that massive changes in district budgetary numbers and programmes occur in the line ministries and NPC, and points out that the NPC sometimes even changes district priorities by allocating a higher amount of budget to nonpriority programmes and substantially reducing the budget for priority programmes. It is concluded that there is lack of full-fledged decentralization-legal, economic, planning and political decentralization - in budget formulation and implementation (UNDP, 2002).

The above view is also supported by Devendra Raj Panday's observation in his book "Nepal's Failed Development' (1999). Policy approval for decentralization and personal dedication of project staff as well as transparency, accountability and good organization (good governance) of the community are vital elements regarding the sustainability of any activity such as water and sanitation at the community level. Schumacher rightly mentioned in his famous book 'Small is Beautiful' that the development does not start with goods; it starts with people and their education, organization and discipline. Without these three, all resources remain latent, untapped potential (Schumacher, 1990)

\subsection{Significant Step Towards Sustainability - A Reality and Rhetoric}

A National Conference in Jhapa, 1980 on "Water and Sanitation Policy Formulation" was instrumental in the matter of formulating policy and procedures to involve the community in all aspects of water supply project, even at least in theoretical framework. The Ministry of Housing and Physical Planning \& Department of Water Supply and Sewerage (MHPP/DWSS) had published "Directives for Water Supply Projects, Construction and Management" in 2046 B.S (1989/1990). This was amended after a year and the main points of that could be summarized as: beneficiaries were mainly responsible for requesting a new water supply scheme, formation of users' committee, users' role in operation, maintenance and repair of the constructed drinking water scheme. And, Nepal National Rural Water Supply Policy \& Guidelines for Planning \& Implementation of Rural Water Supply Program (DWSS, 1994), is the notable step towards recognizing the government's role as facilitator rather than the implementing agency.

Another crucial decision in rural water supply was to establish a Rural Water Supply and Sanitation Fund (RWSSFUND) in 1990 to provide drinking water and sanitation of the needy communities through the support organizations, the private sectors (mostly NGOs), CBOs and direct communities partnership. It was the pilot project with 18.1 million US dollars (Legarian 1994, and Pfohl 1993 quoted by Narayan, 1995), which is still being implemented in the different parts of Nepal.

HMG-Nepal/FINNIDA, the Rural Water Supply and Sanitation Project (RWSSP)- Lumbini Zone of Nepal (1990-1996, 1996-1999, 1999-2003, First, Second, and Third Phases respectively) has striven to implement the water and sanitation activity. The implementation procedures followed step-by -step approach 
developed during the first phase and continuously streamlined which comprised of: (i) request from users; (ii) first screening; (iii) feasibility study; (iv) training of health workers and school teachers; (v) health and sanitation behavior data collection; (vi) selection of the scheme area; (vii) village preparation; (viii) health education and sanitation campaign; (ix) signing of memorandum of understanding- agreement; (x) detailed survey; (xi) designs, cost estimates and bill of quantities; (xii) tendering; (xiii) construction; and (xiv) completion ceremonies and procedures; and follow-up, to hand over stake to the concern community in all the project cycle of the project implementation and management in order to make scheme sustainable. During this first phase, the counterpart or executing agency of RWSSP was MHPP/DWSS at the central level and District Water Supply Office (DWSO) at the district level. The HMG-N/FINNIDA- RWSS Project in the first phase had put its efforts to implement water supply and sanitation activity by the intended community rather than hiring a contractor. During that period, 54 villages development committees (VDCs) through water users' had implemented 110 drinking water schemes serving 234,052 people and 315 institutional toilets were constructed in the six districts of Lumbini Zone. During the second phase of (19961999) the RWSS Project, changed its implementing partner from MHPP to MLD at the central level and at the District level DDC from DWSO. Till 1999, 123,681 (102,181 second phase and 21500 completed from remaining from first phase) people were served by the improved drinking water supply schemes, namely, gravity flow, shallow wells, tubewells and rainwater collection tanks. And in the third phase, it was estimated to serve 216.000 people with drinking water and 52000 people with sanitation facilities. During this phase, two districts, namely, Parbat and Tanhaun, from Dhawalagiri and Gandaki Zones, respectively were also included (RWSSSP Booklet,). In spite of the progress made during the first and second phases of RWSS project tenures, critics pointed out that the process of fostering decentralization has not yet achieved (Sharma, 2001). ADB funded Fourth Rural Water Supply and Sanitation Sector Project (1997-2001) had covered 40 districts and served 850,000 population, much higher than the initially set target. In this phase, the Project Management had given the due importance of capacity building by providing training to 25,000 people. (Paribartan, 2058
BS). A recent survey estimates that 80 per cent of households in Nepal have access to piped or tubewell water (UNDP, 2002).

Almost all the donor-funded projects/agencies working on water and sanitation sector conduct more or less similar types of trainings/workshops/seminars to make the concerned community more aware of their roles and responsibilities. In the series of trainings/seminars/ workshops organized by different support organizations, there are three phases, which comprise the inputs during pre-construction, construction and post construction phases. The example given below is the pre-construction training for Water and Sanitation Users' Committee. The duration of the training could vary according to the emphasis of the organization/s (six days duration is an sample) and the topics are as follows: First day program includes registration of the participants, welcome, opening remarks, introduction about the support organization (SO), indicating the best possible outcome, objective of the training, process of project implementation, (briefing on flow-chart), and role and responsibilities of water and sanitation users' committee on scheme management. Second day includes introduction of scheme area, understanding about the memorandum of understanding and the role and responsibilities of concerned parties, namely, SO and Water Users Committee (WUC), regarding overall responsibilities of WUC on the management of scheme, people's participation and labor contribution. Third day includes how to manage books of account and record keeping, maintenance/operation fund collection and its use, provision of maintenance worker, her/his role and responsibilities. Forth day includes understanding of the interrelationship among water, health and sanitation, connection between drinking water and sanitation activities, techniques/methods on how to keep water safe, its benefits, causes \& consequences due to the use of unsafe water, and its methods of prevention, transmission of diseases by fecal oral routes, its negative effects, and its prevention, and importance \& urgency of construction, and use of latrine. Fifth day includes construction of latrine (practical), and sharing of experience. And sixth day includes role and responsibilities of women health volunteer/youth volunteers, evaluation of the program and closing remarks. Similarly, during the construction and post construction different training/seminars/workshops could be organized especially to provide support to strengthen the concerned community in the 
overall aspects of decision-making and management of any development initiatives focusing more on their capacity building.

The anecdotal cases assembled from a few rural water supply schemes from donor- funded projects indicate the increasing role of users as mangers for the design, implementation, operation and maintenance. Since DWSS has formulated guidelines in order to make a drinking water supply schemes sustainable by strengthening users' (users' representatives) roles and responsibilities. In this connection, the Participatory Rural Appraisal (PRA) tools have been used (since 1990 in FINNIDAfunded water and sanitation projects) for collecting information, preparing plan, implementation, and evaluation of the water supply schemes. The boxes below give examples on how the concerned people's involvement from information to evaluation phases to sustainability of the water supply and sanitation activities.

\section{Box: 2}

\section{Users as Managers}

Rural Water Supply and Sanitation Support Programme (RWSSSP) emphasizes the active participation of stakeholders at all levels to increase their feeling of ownership. Users are considered as owners and managers of their scheme from the very beginning. Each phase (from inception to maintenance/operation) of the scheme calls for the active involvement of rural communities in a step-by-step manner. This approach has been developed to involve the villagers in the planning and implementation and to maximize the proper use of local resources and facilities. In the step-by-step process the user committee (users' representatives) is trained on -the -job to organize and implement their scheme and to improve sanitation in the community. All construction funds are channeled through the respective user committee account, which it operates independently. Villagers collect local materials (sand, aggregate, stones, wood) and provide unskilled labour for the construction work free of charge. They also contribute money for construction and collect fund for the future maintenance needs of their facilities. Users are responsible for the operation and maintenance of their facilities after the construction is completed. The user committees and users are trained and supported in their activities by local NGOs, private firms and government line agencies.

Source: Booklet, HMG-N/FINNIDA, RWSSSP, Nepal Phase III 1999-2003.
Interactive participation in information collection, planning, implementation, collection of maintenance \& operation fund, and participation in different trainings/workshops become generally accepted practices in the donor-funded drinking water supply schemes in the rural areas. The concerned communities, of late, leap forward to use the 'idle maintenance fund' (which has been kept in the bank account) to have access as a revolving loan, to the needy (poor/poorest) members. Among many, the RWSSSP Phase III, 'After Water Supply and Sanitation' "Nayabelhani Stepping Towards Self-Reliance"- (Risal, 2001), is a good example of how people decide what they really want. Similarly, NEWA funded drinking supply scheme management committee had also initiated such activity, which is depicted below in the box.

\section{Box: 3}

Increase in Fund by Mobilizing the Operation and Maintenance Fund

Community Service Center-Janakpur, with the financial and technical assistance of Nepal Water Aid (NEWA), had implemented Drinking Water Supply, Health Education and Sanitation Project in Suganikas Village Development Council area. The project management committee had demonstrated the exemplary work in increasing fund. The committee was comprised of 3 women and 7 men and installed 47 tubewells. For the maintenance purpose each household had paid NRs. 400/- and for operation purpose (may be for salary of maintenance workerclarification is mine) NRs. $5 /$ - per month from each household. The maintenance fund had been deposited in Nepal Bank LimitedJanakpur Branch. After some time, community members realized that if they utilize that fund on revolving basis, the poor would have access to the most wanted capital for their initiation of any income generation activities (IGA). From the first time, they provided loan for 5 people at the $2 \%$ interest per month for IGAs.

Source: Karki, L., et al, PANI (Water), Year-1, Vol.: 2, Water for Health (NEWA) 2057 BS, Quarterly News Bulletin. (Gist translated from Nepali version) 
The above mentioned cases provide the examples of the role of users' on water supply and sanitation from data collection phase to management phase.

The quality, quantity and realibiality of drinking water supplies is questionable, even in the cities. Very high levels of e. coli contamination have been reported in the water supplies of urban areas of the Kathmandu valley. Nepal spends about 3 per cent of its total national budget on drinking water and sanitation (UNDP, 2002). "Come summer, and there goes the usual tale of woe. Water! Water! People run here and there to collect drops of water, literally. And people of Kathmandu Valley, especially in area such as Naradevi, Yetkha and Chhetrapati (may be all parts of Kathmandu valley, except VIP area/s- within parenthesis are mine) are going through hell. The supply of drinking water is erratic, and even if you are lucky enough to get a bucket of water, it is full of filthy substance. It is yellowish. A letter (Water Woe, The Kathmandu Post: 13 May 2002) sent by Rita Shrestha, inhabitant of Chhetrapati, Kathmandu. Despite the progress made so far even in the capital, the development hub of Nepal, the reality is like this. Another vivid example is the ...Jiri DWSO, installed seven community tap-stands without linking them with the source. Indeed, the source was not even sought not because the Office lacked technical expertise, but because the budget had already been allocated ... (Box 4.3- Putting the Cart Before the Horse, UNDP, 2002). Therefore, the progress documented on $80 \%$ of population coverage by the safe drinking water seems to be intricate, rhetorical and confusing. Even the best theory/law/rule/regulation is fruitless unless it is put into real practice.

\subsection{Key Concerns- Knocking Everybody's Door}

$\Rightarrow \quad$ There should be a full-fledged decentralization-legal, economic, planning and political decentralization - in budget formulation and implementation of any developmental activity at the hand of the grass- roots level organization, i., e., Village Development Committee. The political will power of the parliamentarians towards the devolution of power to empower the (rural) poor is the prerequisite for fostering genuine people's participation.

$\Rightarrow \quad$ To institutionalize the real people's participation from the beginning of the project/program cycle, vision and mission building, organizational management system, financial management systems, organizational accountability norms, linkages, and learning evaluation efforts (Fernandez, 2000 ), should be incorporated in the project planning and be actually translated into the practice. Unless these components are evolved at the community-based organization, the people's participation may not be institutionalized. Policy makers should facilitate the process congenial to strengthening the grass-roots organization, and be willing to hand over the stake to the local people. There should also be sanction of more resources for public sector investment, keeping in mind the equity issues.

$\Rightarrow \quad$ The government should always remember and internalize that the "wearer knows where the shoes pinch" and let the wearer to choose the shoes which could fit (and afford) well on her/his feet. Only then the intended community members may own any project/program/activity, which will ultimately be sustainable. It is true in the rural water supply and sanitation program.

$\Rightarrow \quad$ Maximum women participation in all the decision-making bodies should be encouraged, especially in the water and sanitation program.

$\Rightarrow \quad$ In every activity, learning, evaluation, and reviewing should be the integral part of any project or program.

\subsection{Conclusions}

For long, the development practitioners of water and sanitation development program thought that development initiative is a matter of technical issue/expertise and the intended community was given no decision-making role in the design and implementation of the water and sanitation schemes. They could take part in unskilled jobs and minor chores and the contractors and engineers did implementation. Consequently, the intended 
people, sooner or later, did not feel that these implemented schemes are "theirs". But gradually, the importance of people's participation in decision-making from information collection to evaluation stages was recognized. However, the weak political will of the top politicians to decentralize the decision-making power at the grass-roots level has been one of the biggest hurdles for achieving genuine people's participation. Decentralization became "a project" to the politicians to be accomplished, and not a behavior, cultural and value system to be imparted (Panday, 1990).

Different organizational options have been emerging to serve the needy people. Looking back to 1960 s and having a comparison now, a great progress with $80 \%$ percentage coverage has been achieved. Increasing emphasis on "software" i., e., management training to users' representatives on system management, collection of maintenance fund from the users', improving personal hygiene and environmental sanitation, technical training on how to handle operation and maintenance aspects by the village maintenance worker for up-keeping and maintaining constructed schemes, is very positive trend. Women, and intended mass participation in the decision-making level is yet to be incorporated for empowering them. Increase in investment by state as well as community in the drinking rural water supply and sanitation activity is needed to serve more people with 'safe" and adequate drinking and affordable sanitation facilities. There should be guidelines as well as supports by line ministry and private sectors to the facilitators and implementers on regularity of supply, service and facility and reliability of quality to be monitored.

But even in Kathmandu, the capital city of Nepal, the focal point of all developments, water quantity and quality for the common people is extremely scarce and contaminated, and progress documented in different reports looks dubious. There should be balanced development with due consideration of equity to the women as well as disadvantaged people to put them in the decision-making level/position. In spite of this, achievement in this sector is encouraging, yet to be more sensitive, responsive towards the people rather only fulfilling target and building structures in the name of people's development.

\section{EFERENCES}

Alexander, K., C., 1994. The Process of Development of Societies, SAGA Publication, New Delhi, Thousand Oaks, London.

Axinn, George H., 1978 New Strategy for Rural Development Collection papers, Michigan State University USA and Tribhuvan university Nepal. Published by Rural Life Associates, Printed in Nepal at Sahayogi press Kathmandu, Nepal

Bista, D. B., 1994. Fatalism and Development, Nepal's Struggle for Modernization, (fifth impression), Orient Longman Ltd. Calcutta.

Blaikie, P., Cameron, J \& Seddon, D. 1982 Nepal in Crises, Growth and Stagnant at the Periphery, Oxford University Press, Delhi, Bombay, Calcutta and Madras

Boot, M. \& Heijnen, H., 1988. Ten Years of Experience, Community Water Supply and Sanitation Programme, Pokhara, Western Development Region, Nepal, Technical Paper No. 26, IRC International Water and Sanitation Centre, The Hague, The Netherlands

Burkey, S., 1993 People First, A Guide to Self-Reliant Participatory Rual Development, Zed Book Ltd., London \& New Jersey.

Chamber, R., 1990. Rural Development: Putting the Last First, Longman Scientific \& Technical Co-published in the United States with John Wiley \& sons, Inc., New York.

DWSS, 1994. Nepal National Rural Water Supply Policy \& Guidelines for Planning \& Implementation of Rural Water Supply Program, MHPP, HMG/Nepal, Kathmandu, Nepal.

DWSS 2058. PARIBARTAN (Change)-Collection of Water and Sanitation, Ashad 2058, Year 1, Vol. DWSS/Fourth Water Supply and Sanitation Sector Project (Nepali).

Fernandez, A. P., 2002 Assessment of Community Based Institution, A Theoretical Framework and a Participatory Methodology, MYRADA Rural Management Systems Series Paper 33MYRADA -Banglore, India 
Giri, B. B., 1992 Water, Environment and Management, Tow ends of the Decade (18th WEDC conference PRE-PRINT) Water, Engineering and Development with the partnership of Nepal Engineering Association, Kathmandu, Nepal.

HMG/FINNIDA (Consultant: Plancenter Ltd.)

Rural Water Supply and Sanitation Programme, Nepal Phase III 19992003 (Leaflet- n.d.), Kathmandu, Nepal.

MHPP/DWSS, 2047 B. S Directives for Water Supply Projects, Construction, DWSS- MHPP, Panipokhari, Kathmandu, Nepal.

NPC 2042 BS The Seventh Plan- (Part-1), National Planning Commission, $\mathrm{HMG} / \mathrm{Nepal}$

NPC 1998. The Ninth Plan, National Planning Commission, HMG/Nepal

Narayan, D., 1994. The Contribution of People's Participation, Evidence from 121 Rural Water Supply Project, Environmentally Sustainable Development Occasional Series No. 1, IBRD/World Bank- USA.

Panday, D. R.,1999. Nepal's Failed Development, Reflections on the Mission and Methods, Nepal South Asia Centre, Kathmandu, Nepal

Pandey, U 1992. Water, Environment and Management, Role of NGOs in water and sanitation (18th WEDC conference PRE-PRINT) Water, Engineering and Development with the partnership of Nepal Engineering Association, Kathmandu, Nepal.

Peter G. B., 1984 Water and Sanitation: Economic and Sociological Perspectives, Global water Washington, D. C. Academic Press INC (Harcut Brace Jovanovich Publisher) London.

Peter G. B., 1988. Ten Years of Experience: Community Water Supply and Sanitation Programme, Pokhara, Western Developmental Region, Nepal. By Peter G. Bourne. Technical paper No.26. IRC International Water and Sanitation Center, The Hague, The Netherlands.

Pradhannang, A. L. 1991 Principal, Integrated Rural Development Project of Nepal, Central Department of Economic, Tribhuvan University, Kirtipur, Kathmandu, Nepal

Prasain, J.N., 1994. An Experience in Community Participation in Rural Development, internal circulation and sharing with the
UNDP funded- (HDI) QUIPS Project Staff, Rakhine State of Myanmar.

Pyakuryal, K., 1993 Community Development as a Strategy to Rural Development-Article published in Occasional Papers in Sociology and Anthropology, Vol.3. Published by Central Department of Sociology and Anthropology, Tribhuvan University, Kirtipur, Kathmandu, Nepal.

Schumacher, E. F., 1990. Small is Beautiful, A study of Economics as if People Mattered, Rupa Co in association with Macdonald \& Co (publishers) Ltd.

Setty D. E., 1985 The Indian Journal of Social Work, Vol. XLVI, No. 1 9April 1985

Sharma, S.2001 Procuring Water, Foreign Aid and Rural Water Supply in Nepal, Nepal waters Conservation Foundation, Kathmandu, Nepal.

Srinivasan, L., 1990. Tools for Community Participation, A Manual for Training Trainers in Participatory Techniques, Published by PROWWESS/UNDP, New York

Stiller F., S.J. \& Yadav, R. P., 1979. Planning for People, A Study of Nepal's Planning Experience by Ludwing Sahayogi Prakashan for Research Center for Nepal and Asian Studies Tribhuvan University, Kathmandu, Nepal (first edition)

Trace, S., \& Whiteside, G 1991.Water, Environment and Management (18th WEDC conference PRE-PRINT) Water, Engineering and Development with the partnership of Nepal Engineering Association, Kathmandu, Nepal.

Kathmandu Post 2002. Water Woe, by Rita Shrestha, The Kathmandu Post, (English Daily) Vol. X No. 84, May 13, 2002, Kantipur Publication, Kathmandu, Nepal.

UNDP, 2002. Nepal Human Development Report-2001, Poverty Reduction and Governance, UNDP, Pulchowk, Kathmandu, Nepal 